\title{
Die kritische Vernunft kann auch lustig sein- Critical Reason can be fun
}

\author{
By Jack Birner
}

I first met Hans Albert in 1974, when together with two friends, Rob de Vries and Berry van Berkel, I participated in the European Forum Alpbach for the first time. We attended the seminar that was led by John Watkins and Walter Kaufmann (who did not always agree with one another, an added value!) and, of course, went to as many of the plenary meetings as possible. At the time, the seminar week and the bulk of the plenary events were still organized during the same period and were included in the fee, neither of which is unfortunately the case any longer. This first taste of Alpbach was so appetizing to us students that we came back the next year, when Alan Musgrave and Noretta Koertge in their seminar shared with us the latest developments in critical rationalism, on verisimilitude and Popper's rationality principle, even before they were published. These were intellectually exciting times, indeed!

Hans' life is intimately entwined with the European Forum Alpbach. In that first year I went there he gave me a copy of his Marktsoziologie und Entscheidungslogik (Albert 1967), on the methodology of economics, with a personal dedication. I read it with great interest and the book has left its traces on me, including the conviction that for most problems in the world an interdisciplinary approach is indispensable.

So, I have known Hans for more than half of his life and two-thirds of mine. What struck me right away was his unrelenting enthusiasm in discussing any argument with anybody at any time of the day or night in any place, no matter if it was one of the class rooms of the old elementary school (which then hosted part of the seminars) or a mountain meadow. His pleasure to engage in debate with people ranging from students to Nobel Prizes, deploying his sharp mind and quick wit, formed quite a contrast with our image of the stuffy 
and self-important Germanic Herr Professor! Another thing that made quite an impression was his seemingly inexhaustible energy: dancing in the local discotheque until closing time did not diminish the ardour of his participation in next morning's seminar.

Over the years I returned to Alpbach several times, both as a participant and as a co-conductor of seminars. The last time was in 2015, the Forum's 7oth anniversary. Hans did John Filling and me the honour of attending the sessions of our seminar on Freedom and Equality, which concentrated on the works of two other great Alpbach figures, Karl Popper and Friedrich von Hayek. Hans was 94 at the time but followed the proceedings with great interest. He kindly invited me for a family dinner at Gasthof Post, where we could talk in more quiet surroundings.

Meeting Hans in my student days has influenced my academic career. My very first academic paper, presented at a small conference of the Carl Menger Society (does it still exist?) in London benefited greatly from the ideas he expounded in Traktat über kritische Vernunft. I criticized Robert Nozick's Anarchy State, and Utopia (Nozick 1974), whose recent publication had caused quite a stir in political philosophy (I have already said that these were thrilling years!). Hans' ideas that moral judgments can be studied more fruitfully as part of a complex of ideas that also include descriptive theories of the world and that moral judgments, too, are criticizable, helped me a lot in this and later papers.

One of Hans' many merits lies in his spreading Popper's critical rationalism in the German-speaking and other countries in mainland Europe. Apart from Germany, the country where his work has perhaps been most influential is The Netherlands. Unfortunately, there, as everywhere else in the world, courses in logic, methodology and the philosophy of (social) science have fallen victim to a misplaced idea of efficiency in education. They have been eliminated from academic programmes at all levels at an alarming rate. The dismal consequences are under the eyes of everybody. tionalism is that by its nature it attracts scholars who firmly believe in the power of critical argument but lack the temperament for creating and main taining the personal networks and other socialseaffolding that are needed to eonfer influence and longevity to its contents Popper himself being a prime example. This, however, does not apply to Hans: his profoundly social attitude added to the fact that he applied the critical method to many areas of intellectual life (including theology: he wrote a thorough criticism of Joseph Ratzinger's ideas (Albert 2008)-though it is probably too bold a hypothesis that Pope Benedict XVI retired because of his criticism) has won him and crit- 
ical rationalism many friends-and enemies! Had more critical rationalists been as and Hans, Popper's thought might have found firmer roots in modern academy.

Another merit of Hans' is that he enriched intellectual discourse with a number of expressions whose clarity and succinctness hits the nail right on its head: Modellplatonismus (or model Platonism, the pernicious habit of many economists to elevate their abstract models to the status of realistic descriptions of the world-the main cause why they failed to foresee the financial crisis), Sicherheitsdenken, Rechtfertigungsdenken (translating these terms would make them lose their edge), parameter induction. I have not been able to trace all of these back to his writings (another one, the Münchhausen trilemma, recurs in many places), but they are clearly part of an oral tradition in critical rationalism.

Dear Hans, you have set an example that is hard to match. Many, many thanks for enriching and enlivening the intellectual environment of the last half century!

\section{References}

Albert, Hans. 1967. Marktsoziologie und Entscheidungslogik. Ökonomische Probleme in soziologischer Perspektive. Neuwied: Luchterhand.

Albert, Hans. 2008. Joseph Ratzingers Rettung des Christentums: Beschränkungen des Vernunftgebrauchs im Dienste des Glaubens. Aschaffenburg: Alibri.

Nozick, Robert. 1974. Anarchy State, and Utopia, New York: Basic Books. 